\title{
Guar Gum as an Edible Coating for Enhancing Shelf-Life and Improving Postharvest Quality of Roma Tomato (Solanum lycopersicum L.)
}

\author{
X. Ruelas-Chacon, ${ }^{1,2}$ J. C. Contreras-Esquivel, ${ }^{1}$ J. Montañez, ${ }^{3}$ A. F. Aguilera-Carbo, \\ M. L. Reyes-Vega, ${ }^{1}$ R. D. Peralta-Rodriguez, ${ }^{4}$ and G. Sanchéz-Brambila ${ }^{5}$ \\ ${ }^{1}$ Department of Food Research, Faculty of Chemistry, Universidad Autonoma de Coahuila, Blvd. V. Carranza, \\ Colonia Republica Oriente, 25280 Saltillo, COAH, Mexico \\ ${ }^{2}$ Department of Food Science and Technology, Universidad Autonoma Agraria Antonio Narro, Calzada Antonio Narro 1923, \\ Colonia Buenavista, 25315 Saltillo, COAH, Mexico \\ ${ }^{3}$ Department of Chemical Engineering, Faculty of Chemistry, Universidad Autonoma de Coahuila, Blvd. V. Carranza, \\ Colonia Republica Oriente, 25280 Saltillo, COAH, Mexico \\ ${ }^{4}$ Department of Polymerization Processes, Research Center for Applied Chemistry, Blvd. Enrique Reyna Hermosillo No. 140, \\ 25253 Saltillo, COAH, Mexico \\ ${ }^{5}$ Russell Research Center-ARS, Quality and Safety Assessment Research Unit USDA, 950 College Station Road, \\ Athens, GA 30605, USA \\ Correspondence should be addressed to X. Ruelas-Chacon; xruelas@yahoo.com, \\ J. C. Contreras-Esquivel; coyotefoods@hotmail.com, M. L. Reyes-Vega; mlrv20@yahoo.com, \\ and R. D. Peralta-Rodriguez; rene.peralta@ciqa.edu.mx
}

Received 3 January 2017; Revised 26 April 2017; Accepted 23 May 2017; Published 15 August 2017

Academic Editor: Maria J. Fabra

Copyright (C) 2017 X. Ruelas-Chacon et al. This is an open access article distributed under the Creative Commons Attribution License, which permits unrestricted use, distribution, and reproduction in any medium, provided the original work is properly cited.

\begin{abstract}
There exists an increasing interest from consumers and scientific community in developing edible-natural-biodegradable coatings to replace commercial wax-based coatings for maintaining postharvest quality of vegetables. In this work, the effectiveness of guar gum coating on various quality characteristics of Roma tomato at $22 \pm 2^{\circ} \mathrm{C}$ over a $20 \mathrm{~d}$ storage period was investigated. Tomatoes were covered with a $1.5 \%$ guar gum coating plasticized with glycerol at $30 \%$ and stored at $22 \pm 2^{\circ} \mathrm{C}$ and $40 \% \mathrm{RH}$ for 20 -d. Tomatoes covered with edible coating significantly enhanced firmness and reduced weight loss, delayed changes on soluble-solids-content, retarded loss of total acidity, and decreased respiration rate compared with uncoated-control fruit. Sensory analysis by trained panelists revealed that the use of the edible coating influenced the acceptability of tomatoes. There were significant differences on the scores given by panelists when comparing the coated and uncoated tomatoes. It was concluded that guar gum affected favorably the physicochemical, microbial, and sensorial quality properties of Roma tomato and therefore could be beneficial in delaying the ripening process at $22 \pm 2^{\circ} \mathrm{C}$.
\end{abstract}

\section{Introduction}

Tomatoes (Solanum lycopersicum L.) have become essential ingredients in the cuisine of many countries. This fruit has limited marketability because of its high moisture content and high degree of perishability which leads to extensive postharvest losses. Storage life is limited by several factors, for example, transpiration, postharvest diseases, increased ripening, and senescence [1]. Of all these factors, the most important is respiration rate, due to its association with tomato postharvest shelf-life, fruit ripening, and deterioration of tomato quality [2].

One way to control tomato ripening is through the manipulation of ambient temperature, gas, and humidity. At low storage temperature, it is possible to maintain freshness and extend shelf-life as the respiration rate and thermal 
decomposition are reduced $[3,4]$. Controlled atmosphere and hypobaric storage can extend shelf-life of tomatoes but these processes are costly. An alternative to extend postharvest life and keep production costs low is the use of edible coatings [5].

Edible coatings generate a modified atmosphere by creating a semipermeable barrier against $\mathrm{O}_{2}, \mathrm{CO}_{2}$, moisture, and solute movement, thus reducing respiration, water loss, and oxidation reaction rates [2]. Different materials have been used as edible coatings and are commonly based on proteins, lipids, or polysaccharides [6]. The great benefit conferred by edible coatings is that these are natural biodegradable products $[7,8]$.

Guar gum is a galactomannan rich flour, water soluble polysaccharide obtained from the leguminous Indian cluster bean Cyamopsis tetragonoloba (L.) Taub. The backbone of this hydrocolloid is a linear chain of D-mannopyranose units connected to each other by $\beta$-1,4-bonds linked to galactose residues by 1,6- bonds forming short side-branches [9-11]. Guar gum is one of the most important thickeners and is a versatile material for many food applications due to its different physicochemical properties as well as its high availability, low cost, and biodegradability. This galactomannan has similar properties as carrageenan, alginate, xanthan gum, and gum arabic as an edible coating but guar gum has the advantage of being cheaper than all the others. Moreover, the availability of guar gum is not a problem since it is produced in the north of Mexico by a Mexican company, Guar Growers Mexico.

The aim of the present study was to evaluate the potential of the guar gum edible coating on the extension of shelflife and maintaining the quality of Roma tomato fruit during a 20 -day storage period at $22 \pm 2^{\circ} \mathrm{C}$. This temperature was selected because there are several studies about postharvest with tomato using room temperature between 20 and $25^{\circ} \mathrm{C}$ $[2,8,12,13]$.

\section{Materials and Methods}

2.1. Plant Material. Freshly harvested tomato (Solanum lycopersicum L. $v c$ Pyriform) fruit at light red stage of ripening according to the USDA standard tomato color classification chart [14] were obtained from a commercial supplier in Saltillo, Mexico. The fruits with an average weight of $14.55 \mathrm{~g}$ were visually sorted for uniformity in size, color, absence of blemishes, and fungal infection. Tomatoes were transported to the laboratory within $1 \mathrm{~h}$ of purchase. Before treatment, fruits were washed with sodium hypochlorite solution $\left(200 \mathrm{mg} \mathrm{kg}^{-1}\right)$ for 2 minutes and air-dried at ambient temperature $\left(22 \pm 2^{\circ} \mathrm{C}\right)$.

2.2. Coating Treatment. Guar gum (G4129-500G) was from Sigma-Aldrich (St. Louis, MO, USA) and glycerol was from Jalmek Co. (Monterrey, Mexico). Guar gum coating solution was prepared using $1.5 \%(\mathrm{w} / \mathrm{v})$ guar gum and $30 \%(\mathrm{v} / \mathrm{v})$ glycerol; $0.3 \mathrm{~mL}$ of glycerol and $1.5 \mathrm{~g}$ of guar gum were dissolved in $100 \mathrm{~mL}$ distilled water, formulation selected according to previous research reported by Ruelas-Chacón et al. (2017).
The solution was stirred at $800 \mathrm{rpm}$ at $60^{\circ} \mathrm{C}$ during 30 minutes on a magnetic stirrer/hot plate (Talboys, Thorofare, New Jersey, USA) [15].

A total of 108 tomato fruits were randomly allotted to two groups: uncoated (UC) and coated (C). Tomatoes in the UC group were immersed in distilled water for 1 minute and the $\mathrm{C}$ group was immersed in the guar gum coating solution for 1 minute. Fruits were air-dried for $5 \mathrm{~h}$ at $22 \pm 2^{\circ} \mathrm{C}$. All samples were left in a chamber at ambient temperature and $40 \% \mathrm{RH}$ for 20 days.

2.3. Weight Loss Percentage. The tomato samples, UC and C, (three samples per repetition) were weighted at days $0,4,8,12$, 16 , and 20 during the storage period. The difference between initial and final fruit weight (to the nearest $0.001 \mathrm{~g}$ ) was considered as total weight loss during the storage intervals and calculated as percentages on a fresh weight basis [16].

2.4. Color. The color characteristics were assessed using a Minolta Chroma Meter CR-400 (Minolta Corp, Ramsey, New Jersey, USA) to measure $L$ (lightness of brightness), $a^{*}$ and $b^{*}$ values. Three measurements were taken for each treatment and the averages of $L, a^{*}$, and $b^{*}$ values were obtained following the procedure described by Maftoonazad et al. [17].

2.5. Firmness. The firmness of tomatoes in each treatment group was determined using a digital Force Gauge penetrometer (PCE-PTR 200, PCE group, Albacete, Castilla la Mancha, Spain), equipped with an $8 \mathrm{~mm}$ plunger tip, at the equator of the fruit where a section of rid $(4 \mathrm{~cm} \times 4 \mathrm{~cm}$, approximately) had been removed. Results were expressed in newtons (N). Three readings were taken for each tomato [4].

2.6. Soluble Solid Concentration (SSC). Three tomatoes per treatment were analyzed at each sampling day $(0,4,8,12$, 16, and 20). Each tomato was ground with a Master Craft processor (Blender 9 in 1 EC51034, Soriana Stores S.A. de $\mathrm{CV}$, Monterrey, Mexico) during $1 \mathrm{~min}$. SSC of the ground tomatoes was measured following the AOAC (1984) method using an ATAGO refractometer (ATAGO, USA Inc., Bellevue, WA, USA) at ambient temperature $\left(22 \pm 2^{\circ} \mathrm{C}\right)$. The SSC concentration was expressed as percentage on the Brix scale.

2.7. Total Acidity (TA). Two milliliters of ground tomato was diluted with $30 \mathrm{~mL}$ of distilled water. The titration of the samples was done with $\mathrm{NaOH} 0.01 \mathrm{~N}$ at $\mathrm{pH}$ 8.3. Three readings for each treatment were recorded per sampled day and the means of these measurements were expressed as citric acid and then used for statistical analyzes $[18,19]$.

2.8. Microbial Analysis. Surface skin $\left(2 \mathrm{~cm}^{2}\right)$ of UC and C tomatoes at $0,4,8,12,16$, and 20 days of storage at ambient temperature was peeled off with a sterile scalpel. Ten grams of skin samples was immersed in $90 \mathrm{~mL}$ of peptone water and vortexed for $2 \mathrm{~min}$ (Vortex-Genie 2, Scientific Industries, Inc., Bohemia, NY, USA). The microbial analysis consisted of a plate count method for aerobic mesophilic bacteria at $30^{\circ} \mathrm{C}$ in 

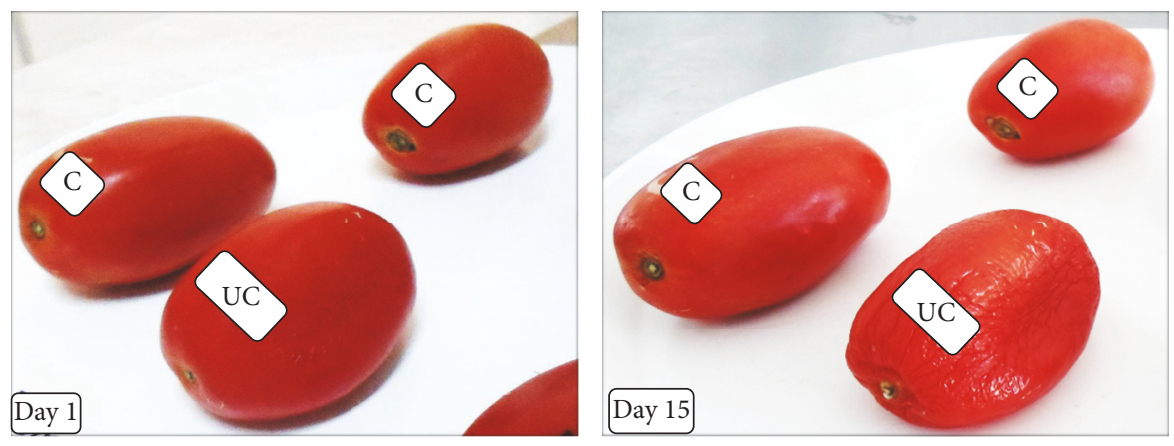

Figure 1: Effect of storage period (day 1 and day 15) on Roma tomatoes coated with guar gum (C) and uncoated (UC), under ambient temperature conditions $\left(22 \pm 2^{\circ} \mathrm{C}\right)$.

plate count agar (PCA) over $48 \mathrm{~h}$ and yeast and molds at $25^{\circ} \mathrm{C}$ in potato dextrose agar (PDA) over $72 \mathrm{~h}$. Visible colonies were counted and CFU/g calculated $[8,20]$.

2.9. Respiration Rate. Respiration of samples was analyzed periodically in a closed and hermetic system. The samples (three tomatoes per jar) were randomly distributed in the glass containers with a capacity of 1.80 liter at ambient temperature $\left(22 \pm 2^{\circ} \mathrm{C}\right)$. The ratio between container capacity and amount of tomato was $600: 100$ (v-w, mL-g). Gas samples were taken from the jar with a needle inserted through a septum fixed at the center of the jar lid. The needle was connected to $\mathrm{CO}_{2} / \mathrm{O}_{2}$ gas analyzer (PBI Dansensor Gas Analyzer, Checkmate II, Denmark). The results in percentage a $\mathrm{CO}_{2}$ were used for calculation of the respiration rate $\left(\mathrm{mL} \mathrm{kg}^{-1} \mathrm{~h}^{-1}\right)$, using the following equation:

Respiration rate is

$$
\% \mathrm{CO}_{2}
$$

(Mass of sample in $\mathrm{kg} *$ hours incubated $*$ volume jar)

2.10. Sensory Evaluation. A panel of 15 trained judges analyzed visual appearance, flavor (taste), and firmness during days 1, 5, and 10 of the storage period. Evaluations were scored based on a nine-point scale $(1=$ extremely poor, $3=$ poor, $5=$ acceptable, limit of marketability, $7=$ good, and $9=$ excellent [20]). The overall appreciation of the sample was measured on the same scale and referred to as overall quality [21].

2.11. Statistical Analysis. Data were subjected to one-way analysis of variance (ANOVA) with three replications, using the JMP 5.0.1 software (SAS Institute Inc. Cary, NC, USA), including a Least Significant Difference Test. The Tukey test was used to compare the mean values in different storage intervals. Statistical differences were declared at $p<0.05$.

\section{Results and Discussion}

The guar gum coating adhered well to the Roma tomato surface and exhibited a transparent appearance. All tomato fruits shrank during the 20-day storage period; coated treatment shrank less rapidly than the uncoated one.

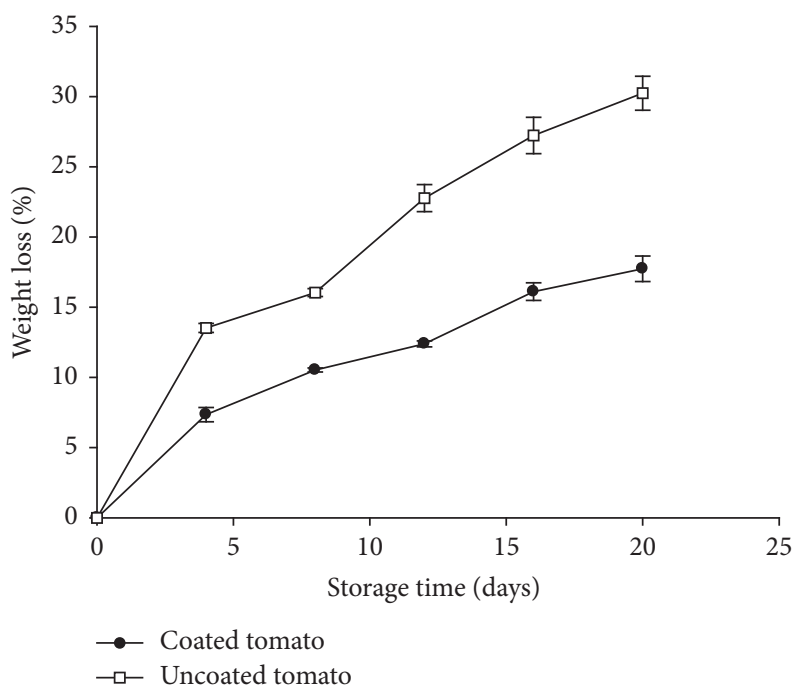

Figure 2: Effect of guar gum coating on weight loss of Roma tomatoes during a 20 -day storage period $\left(22 \pm 2^{\circ} \mathrm{C}\right)$.

3.1. Weight Loss. Figure 1 shows changes on tomato fruits (UC and C) from day 1 and day 15 during storage time. UC tomato from day 15 lost weight and shrank, and $\mathrm{C}$ tomatoes, at the same time of storage, look different compared to the UC fruits. Visually the difference is evident, so the application of guar gum coating retarded the weight loss of tomato fruit during the storage period.

Figure 2 shows the weight loss of the UC and $\mathrm{C}$ tomatoes. The fruits exhibited significant difference $(p \leq 0.05)$ : the $\mathrm{C}$ tomatoes exhibited comparatively lower weight loss than the UC fruits. It can be inferred that the guar gum coating formed a semipermeable layer, which allows passage of certain small molecules but acts as a barrier to others, and acted as protective barrier to reduce respiration and transpiration on the fruit surface and conferred a physical barrier against $\mathrm{O}_{2}$, $\mathrm{CO}_{2}$, moisture, and solute movement, reducing water loss $[12,22]$.

Our results are in agreement with findings of Ali et al. [2], where water loss of tomato fruit was reduced by coating with gum arabic. Rice starch-based coating has been effective in controlling weight loss in tomatoes stored at room temperature [8]. Ahmed et al. [20] used delactosed whey 
TABLE 1: Changes in $L, a^{*}, b^{*}$, and chroma $\left(C^{*}\right)$ color values of guar gum coated tomatoes at different storage time intervals.

\begin{tabular}{|c|c|c|c|}
\hline Color parameter & Storage time (days) & Uncoated & Coated \\
\hline \multirow{6}{*}{$L$} & 0 & $42.59 \pm 0.51^{b}$ & $43.49 \pm 0.55^{\mathrm{a}}$ \\
\hline & 4 & $44.89 \pm 0.61^{\mathrm{b}}$ & $46.05 \pm 0.31^{\mathrm{a}}$ \\
\hline & 8 & $39.43 \pm 0.14^{\mathrm{b}}$ & $41.63 \pm 0.89^{\mathrm{a}}$ \\
\hline & 12 & $44.46 \pm 0.25^{\mathrm{b}}$ & $49.24 \pm 0.30^{\mathrm{a}}$ \\
\hline & 16 & $44.82 \pm 0.21^{\mathrm{b}}$ & $44.81 \pm 0.26^{\mathrm{a}}$ \\
\hline & 20 & $43.52 \pm 0.28^{b}$ & $45.08 \pm 0.39^{\mathrm{a}}$ \\
\hline \multirow{6}{*}{$a^{*}$} & 0 & $22.33 \pm 0.26^{\mathrm{a}}$ & $20.46 \pm 0.56^{\mathrm{b}}$ \\
\hline & 4 & $24.66 \pm 0.24^{\mathrm{a}}$ & $20.81 \pm 0.74^{\mathrm{b}}$ \\
\hline & 8 & $26.00 \pm 0.89^{\mathrm{a}}$ & $19.77 \pm 0.61^{b}$ \\
\hline & 12 & $26.74 \pm 0.68^{\mathrm{a}}$ & $20.90 \pm 0.73^{b}$ \\
\hline & 16 & $27.78 \pm 0.89^{\mathrm{a}}$ & $22.77 \pm 0.77^{\mathrm{b}}$ \\
\hline & 20 & $28.91 \pm 0.55^{\mathrm{a}}$ & $23.76 \pm 0.91^{\mathrm{b}}$ \\
\hline \multirow{6}{*}{$b^{*}$} & 0 & $21.39 \pm 0.73^{\mathrm{a}}$ & $19.46 \pm 0.94^{\mathrm{a}}$ \\
\hline & 4 & $18.18 \pm 0.89^{\mathrm{a}}$ & $18.78 \pm 0.86^{\mathrm{a}}$ \\
\hline & 8 & $20.38 \pm 0.93^{\mathrm{a}}$ & $20.00 \pm 0.75^{\mathrm{a}}$ \\
\hline & 12 & $23.24 \pm 0.34^{\mathrm{a}}$ & $18.91 \pm 0.23^{\mathrm{a}}$ \\
\hline & 16 & $13.17 \pm 0.36^{\mathrm{a}}$ & $17.64 \pm 0.95^{\mathrm{a}}$ \\
\hline & 20 & $20.32 \pm 0.16^{\mathrm{a}}$ & $17.41 \pm 0.94^{\mathrm{a}}$ \\
\hline \multirow{6}{*}{$C^{*}$} & 0 & $30.92 \pm 0.83^{\mathrm{a}}$ & $28.24 \pm 0.66^{\mathrm{b}}$ \\
\hline & 4 & $30.64 \pm 0.79^{\mathrm{a}}$ & $28.03 \pm 0.79^{b}$ \\
\hline & 8 & $33.03 \pm 0.43^{\mathrm{a}}$ & $28.12 \pm 0.84^{\mathrm{b}}$ \\
\hline & 12 & $35.43 \pm 0.89^{\mathrm{a}}$ & $28.19 \pm 0.27^{\mathrm{b}}$ \\
\hline & 16 & $33.19 \pm 0.76^{\mathrm{a}}$ & $29.42 \pm 0.67^{b}$ \\
\hline & 20 & $35.34 \pm 0.20^{\mathrm{a}}$ & $29.46 \pm 0.38^{\mathrm{b}}$ \\
\hline
\end{tabular}

${ }^{\mathrm{ab}}$ Means in the same raw followed by a different superscript differ by Tuckey's test at $p \leq 0.05$.

coating on tomatoes and reduced weight loss during storage period, the application of protein-phenolic based coating on tomatoes also retarded weight loss [12], and El-Ghaouth et al. [23] using chitosan on tomatoes extended shelf-life by reducing weight loss and other quality postharvest parameters.

Chitosan coatings have been effective in controlling weight loss from other vegetables, including papaya [24], cucumber and pepper [23], longan fruit [25], and strawberry fruit [26]. The obtained results are also in good agreement with the findings by Bai et al. [27] who reported that an efficient reduction in weight loss was found in coated "Delicious" apples.

3.2. Color. The changes on CIELAB parameters of $\mathrm{C}$ and UC tomatoes during the storage time at ambient temperature $\left(22 \pm 2^{\circ} \mathrm{C}\right)$ are shown in Table 1 . There was a significant difference in $L$ values when comparing the treated and untreated tomatoes. $\mathrm{C}$ tomatoes presented a higher visual brightness compared to the UC samples. It is important to say that there were not significant differences between fruits during the storage period.

These results agree with findings of Athmaselvi et al. [28] and Santoso and Rahmat [29], where $L$ values were higher for tomatoes treated with Aloe vera based edible coating. Parameter $a^{*}$ was different $(p \leq 0.05)$ between treatments during the 20-day trial; $a^{*}$ values change from light red reading to red color [30]. The $a^{*}$ values (red color) for UC tomatoes were higher $(p \leq 0.05)$ than for the $\mathrm{C}$ ones, whereas no differences were observed on $b^{*}$ values between the UC and the $C$ fruits. This could be attributed to the modified atmosphere in the fruit created by the guar gum coating which influenced the respiration rate delaying color variation between treatments more than on the storage period itself.

The chroma $\left(C^{*}\right)$ values were maintained during storage on $\mathrm{C}$ tomatoes (Table 1 ) and they significantly increase in UC samples after storage. The higher $C^{*}$ values on UC samples indicated higher saturation related to the redness stage of ripening.

During ripening, the green pigment chlorophyll degrades and carotenoids are synthesized [31] from colorless precursor (phytoene) to carotene (pale yellow), lycopene (red), $\beta$-carotene (orange), xanthophylls, and hydroxylated carotenoids (yellow) $[5,32]$ given the variation in the values of color parameters.

3.3. Firmness. In this study, firmness of fruit decreased ( $p \leq$ 0.05 ) with storage time in both $\mathrm{C}$ and UC fruit (Figure 3 ). The firmness of UC tomatoes decreased $(p \leq 0.05)$ more rapidly than $\mathrm{C}$ tomatoes. After the fourth day, deterioration of firmness increased substantially and steadily, being more accentuated in UC fruits. Reduction of firmness in the UC sample was $72 \%$ compared to $46 \%$ of the C tomatoes after 20 days of storage (Figure 3). Firmness data were correlated versus respiration rate and the Pearson correlation 


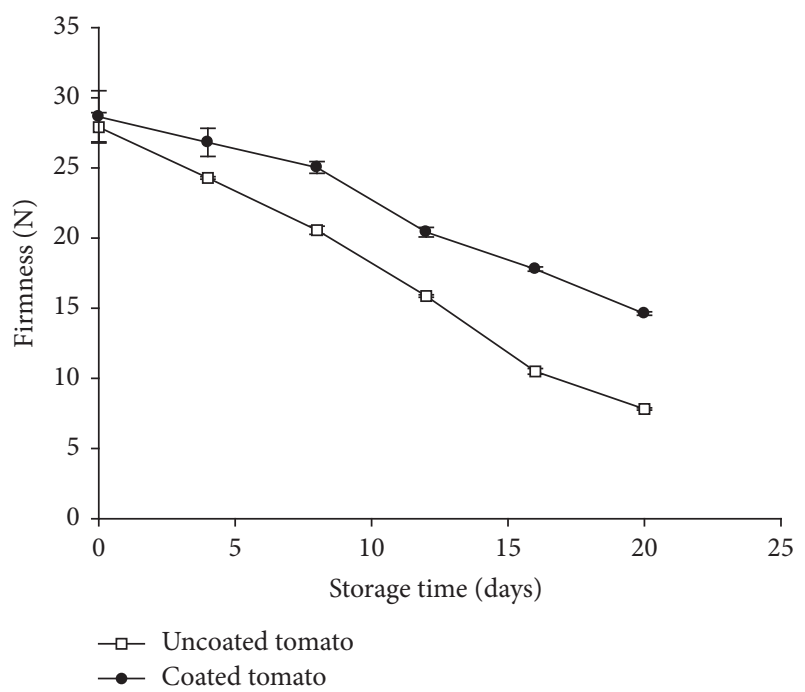

Figure 3: Effect of guar gum coating on the firmness of Roma tomatoes during a 20 -day storage period $\left(22 \pm 2^{\circ} \mathrm{C}\right)$.

coefficient was -0.763 , meaning that if values of respiration rate increased the values for firmness decreased, probably due to the enzymatic activities during the ripening process $[29,33,34]$. Softening of fruits is due to deterioration in the cell wall composition [33] and it is a biochemical process involving the hydrolysis of pectin and starch by enzymes such as hydrolases, pectinesterase, and polygalacturonase [34]. High levels of $\mathrm{CO}_{2}$ propitiated by coating on the fruit can limit the activity of these enzymes which allows maintenance of firmness during storage.

3.4. Soluble Solids Concentration. In general, there was a gradual increase in SSC during the complete storage period (Figure 4). For UC samples were $18.2 \%$ whereas for C fruits were only $4.26 \%$ (Figure 4 ). The SSC at 20 days of storage was higher $(p \leq 0.05)$ in UC (5.5\%) compared to C fruits $(4.7 \%)$ from the initial SSC which was $4.5 \%$ for UC and C tomatoes.

The lowest SSC at the end of the storage period was recorded in fruit coated with guar gum and showed that the coatings provided a good semipermeable barrier around the fruit, modifying the internal atmosphere by reducing or elevating $\mathrm{CO}_{2}$ production. As a result, decreased respiration rates slowed down the synthesis and use of metabolites resulting in lower SSC $[2,18,34]$. Variations in SSC are correlated with hydrolytic changes in polysaccharides (hemicellulose and pectin) with ripening in postharvest storage. The degradation of the cell wall polysaccharides that occur during storage period in tomatoes leads to the release of oligosaccharins which can affect fruit ripening [8].

3.5. Total Acidity. In the present trial, total acidity values of $\mathrm{C}$ and UC fruit during storage decreased with storage time (Figure 5) and the values were higher $(p \leq 0.05)$ in UC fruit $(0.41 \%)$ compared to the $\mathrm{C}$ samples $(0.35 \%)$. This response occurs because the citric acid content increases with maturity and stage of ripening $[3,22]$; however, once fruit reach the full ripe stage, citric acid content starts to decline [35]. The guar

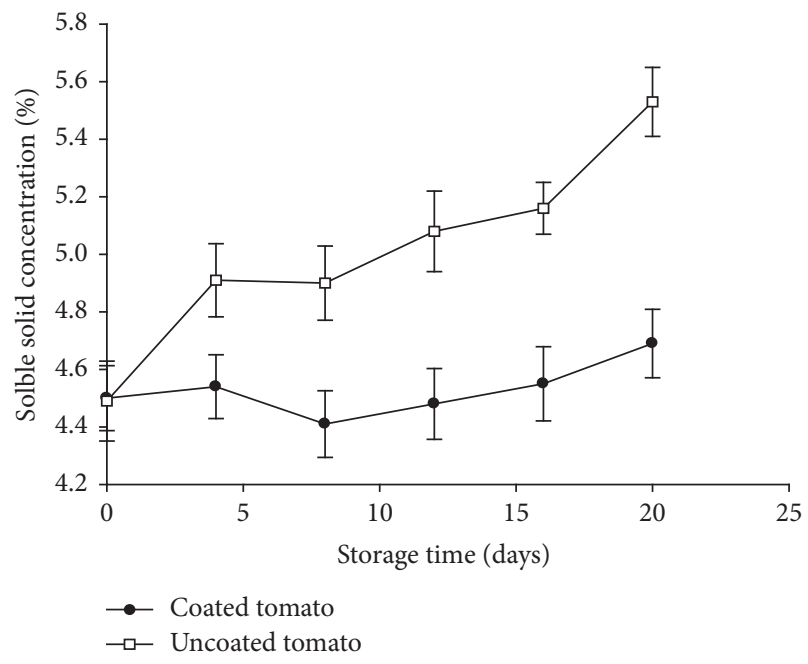

FIGURE 4: Influence of guar gum coating on the soluble solid concentration of Roma tomatoes during a 20-day storage period $\left(22 \pm 2^{\circ} \mathrm{C}\right)$.

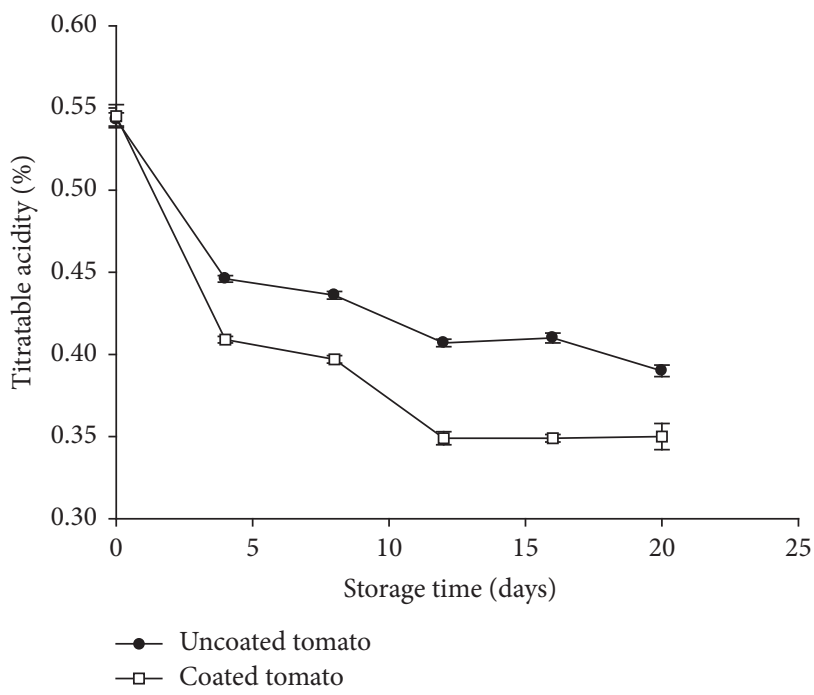

FIGURE 5: Total acidity response of tomatoes coated with guar gum during a 20 -day storage period at ambient temperature $\left(22 \pm 2^{\circ} \mathrm{C}\right)$.

gum coating slowed down the synthesis of citric acid during ripening; this effect is shown in Figure 5. The higher TA level in control fruit suggests that coating delayed ripening by providing a barrier against $\mathrm{O}_{2}$ uptake around the fruit $[33,36,37]$.

The acidity of tomato is very important for the taste of the fruit. The effect of coating on internal quality parameters is dependent on coating type, fruit cultivar, and storage conditions. In tomato, Das et al. [8] found greater values for TA in uncoated fruit than in fruit coated with rice starch-based coatings. This was attributed to higher ethylene production and respiration rate in uncoated fruit during ripening. In the same trial, higher values of TA were also reported in uncoated than in coated tomatoes. The higher TA values on uncoated samples than on coated ones were attributed to the loss of citric acid in tomatoes as fruit ripened $[13,38]$. 
TABLE 2: Microbial plate counts of uncoated and coated (edible guar gum) Roma tomatoes.

\begin{tabular}{lcccc}
\hline & \multicolumn{2}{c}{ Uncoated } & \multicolumn{2}{c}{ Coated } \\
\hline $\begin{array}{l}\text { Storage time (days) } \\
\begin{array}{l}\text { Mesophilic bacteria } \\
\text { (CFU/g) }\end{array}\end{array}$ & $480^{\mathrm{a}}$ & $1460^{\mathrm{a}}$ & $480^{\mathrm{b}}$ & $960^{\mathrm{b}}$ \\
$\begin{array}{l}\text { Yeast and molds } \\
\text { (CFU/g) }\end{array}$ & $520^{\mathrm{a}}$ & $1580^{\mathrm{a}}$ & $530^{\mathrm{b}}$ & $1030^{\mathrm{b}}$ \\
\hline
\end{tabular}

Means followed by different letters in the same column are significantly different by Tuckey's test $p \leq 0.05$.

3.6. Microbial Analysis. Microbial count for mesophilic bacteria and yeast and molds increased as storage time increased for both treatments (Table 2). The colony forming units $(\mathrm{CFU} / \mathrm{g})$ for mesophilic bacteria were different $(p \leq 0.05)$ for UC tomatoes from days 0 to 20 (480 and $1460 \mathrm{CFU} / \mathrm{g})$. In $\mathrm{C}$ tomatoes, there was also a significant difference from days 0 to 20 (480 and $960 \mathrm{CFU} / \mathrm{g}$ ) but the $\mathrm{CFU} / \mathrm{g}$ on $\mathrm{UC}$ samples were higher than in $\mathrm{C}$ ones. The $\mathrm{CFU} / \mathrm{g}$ values for yeast and molds showed significant differences $(p \leq 0.05)$ between treatments. The CFU/g for UC samples were 520 and $1580 \mathrm{CFU} / \mathrm{g}$ for days 0 and 20, respectively. Regarding the $\mathrm{C}$ fruits, the CFU/g were 530 for day 0 and 1030 for day 20. Pearson's correlation coefficient for mesophilic bacteria versus respiration rate was 0.978 and for yeast and molds versus respiration rate was 0.980 ; these are strong correlations between variables. As the respiration rate of the fruits increased the deterioration of the fruit does too, given the conditions such as nutrient availability for the microorganisms to develop. The protective effect provided by the edible guar gum coating seems to reduce the rate of development of microorganisms that affect the quality of tomatoes, because the coating acts as a barrier of gases and other substances such as water or other nutrients needed for the growth of microorganisms [39]. Further, protective coating offers an additional barrier to microorganism contamination during storage. This is also evident from results reported here.

3.7. Respiration Rate. The effect of coatings on respiration rate of Roma tomatoes stored at ambient temperature $\left(22 \pm 2^{\circ} \mathrm{C}\right)$ is shown in Figure 6. All samples increased the respiration rate during storage, which indicates an increase in the fruit metabolic activity. After $20 \mathrm{~d}$, the $\mathrm{C}$ tomatoes had the lowest $\mathrm{CO}_{2}$ production $\left(2.8, \mathrm{~mL} \mathrm{~kg}^{-1} \mathrm{~h}^{-1}\right)$ compared with the UC tomatoes $\left(10.7, \mathrm{~mL} \mathrm{~kg}^{-1} \mathrm{~h}^{-1}\right)$, indicating that coating might have modified the internal atmosphere and significantly delayed respiration rate of Roma tomatoes. Respiration rate in fresh fruit and vegetables is considered good index for determination of storage life [38]. The effect of polysaccharidebased coatings on respiration of horticultural products is related to their ability to create a barrier to oxygen diffusion through the coating [40]. In tomatoes, coatings based on gum arabic [38], alginate or zein [41], and hydroxyl propyl methyl cellulose (HPMC) also reduced the fruit respiration rate during storage $[7,42]$.

A reduction in respiration rate as a result of coating has also been reported by many researchers in various fruit, such

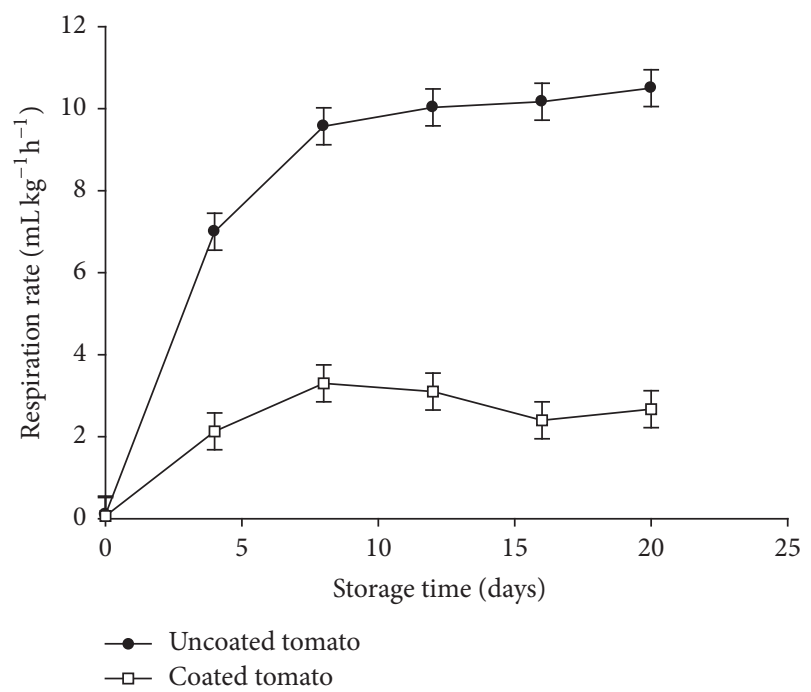

FIGURE 6: Influence of guar gum coating on the respiration rate of Roma tomatoes during a 20-day storage period at ambient temperature $\left(22 \pm 2^{\circ} \mathrm{C}\right)$.

as papaya, grapes, mango, strawberries, and tomatoes $[23,24$, $29,39,43]$.

3.8. Sensory Evaluation. Sensory evaluation of C and UC fruit at the end of the storage period revealed differences ( $p \leq$ 0.05 ) in appearance, flavor, firmness, and overall acceptability (Figure 7). On day 0, there were no significant differences $(p \leq 0.05)$ detected for all the attributes evaluated. As storage time increased (Figure 7; days 5 and 10), there were significant differences $(p \leq 0.05)$ detected by the panelists in favor of the $\mathrm{C}$ tomatoes on appearance, flavor, firmness, and overall acceptability. The effect of guar gum coating on tomatoes helps to slow down the ripening process $[29,39]$ that influence the quality attributes of the samples evaluated. On Figure 7, it can be seen that there were significant differences on appearance, flavor, firmness, and overall acceptability of $\mathrm{C}$ and UC tomatoes. Other authors report similar findings: the application of a coating helps maintain texture firmness $[13,29,39]$, color, and flavor changes [2, 13, 38, 39], on different products such as apples, and tomatoes, using several types of coatings at ambient temperature $\left(22 \pm 2^{\circ} \mathrm{C}\right)$.

The scores given by the panelists to all the attributes were between 9 and 7, which is interpreted as "excellent" to "good." These results suggest that the guar gum coating can be used to prolong the shelf-life and improve tomato quality during storage at ambient temperature $\left(22 \pm 2^{\circ} \mathrm{C}\right)$. C and UC Roma tomato were not sensory analyzed after 10 days of storage based on the microbiological results.

\section{Conclusions}

The present study shows that coating Roma tomatoes with guar gum delayed the ripening process by inhibiting the respiration rate of this fruit. This suggests that guar gum coating not only maintained firmness but also improved the postharvest quality during storage at ambient temperature. 

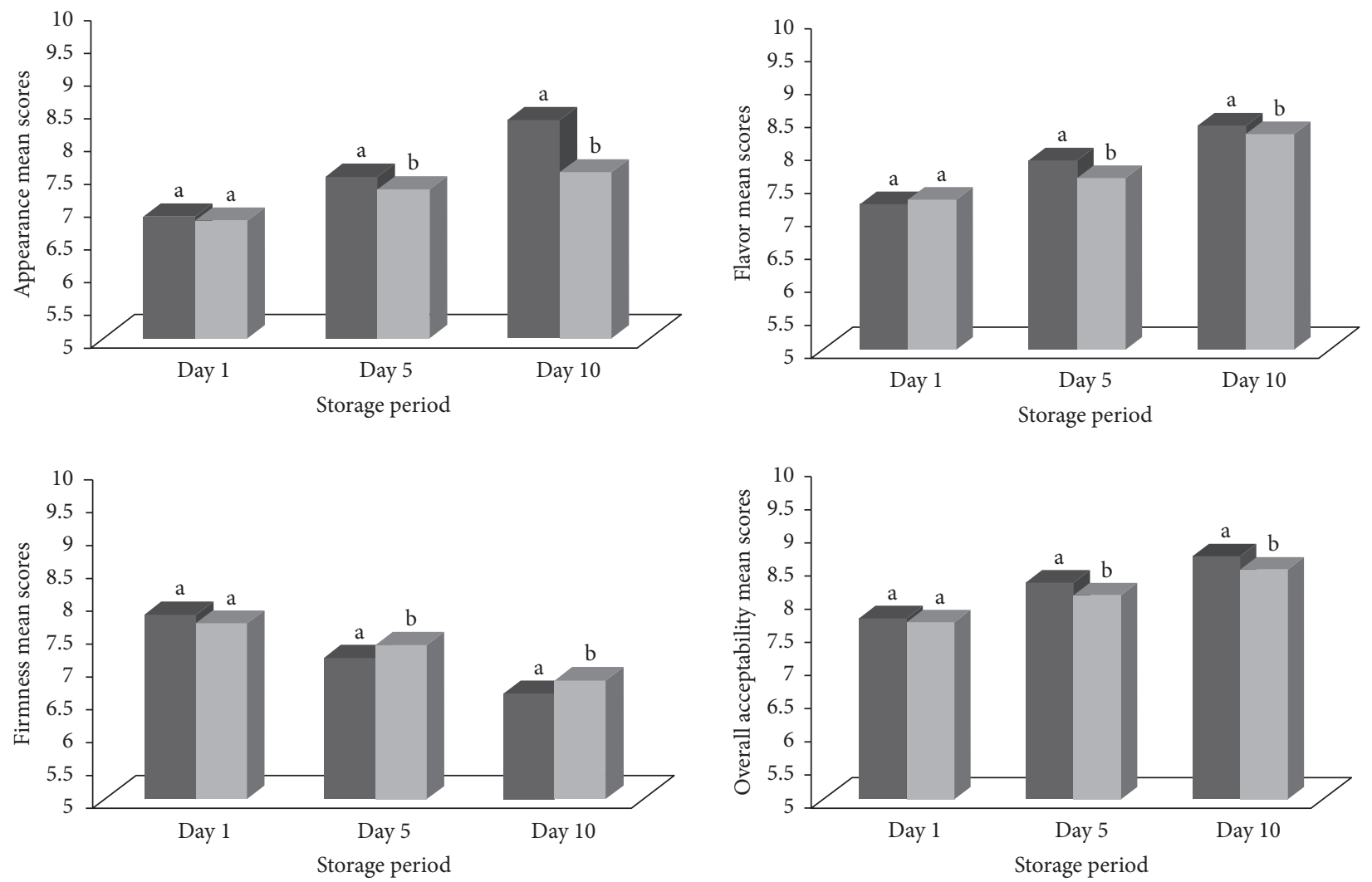

Figure 7: Sensory evaluation of uncoated (dark gray) and coated (light gray) tomatoes stored at $22 \pm 2^{\circ} \mathrm{C}$ for 10 days. Scores designated by different letters are significantly different $(p \leq 0.05)$ for each attribute. Three different trials were carried out in triplicate. The scale corresponds to $9=$ excellent and $1=$ extremely poor.

The guar gum coating is biodegradable, easily applied, and less expensive (compared with other hydrocolloids and commercial waxes) and it can be used commercially to prolong the storage life of Roma tomatoes.

For future studies, it is still necessary to improve its water vapor barrier properties, perhaps by adding specific lipid components in order to increase the postharvest storage quality at ambient temperature and cold storage.

\section{Conflicts of Interest}

The authors declare that they have no conflicts of interest.

\section{Acknowledgments}

The authors are grateful to the National Council of Science and Technology (CONACYT), Mexico, for the financial support through a Ph.D. scholarship for Ruelas-Chacon, M.S., and to the Universidad Autonoma Agraria Antonio Narro (UAAAN), Saltillo, Mexico, for the permission granted to Ruelas-Chacon, M.S., to study a Ph.D. degree. Partial financial support from CONACYT through Project CB2011/168472 granted to author Peralta-Rodriguez to carry out this research and publishing financial support with PFCE 2016 are gratefully acknowledged.

\section{References}

[1] H. R. El-Ramady, É. Domokos-Szabolcsy, A. A. Neama, S. T. Hussein, and F. Miklós, "Postharvest Management of Fruits and Vegetables Storage," in Sustainable Agriculture Reviews, pp. 65152, Lichtfouse, Switzerland, 2015.

[2] A. Ali, M. Maqbool, S. Ramachandran, and P. G. Alderson, "Gum arabic as a novel edible coating for enhancing shelflife and improving postharvest quality of tomato (Solanum lycopersicum L.) fruit," Postharvest Biology and Technology, vol. 58, no. 1, pp. 42-47, 2010.

[3] F. M. Mathooko, "A comparative study of the response of tomato fruit to low temperature storage and modified atmosphere packaging," African Journal of Food Agriculture Nutrition and Development, vol. 2, pp. 34-41, 2003.

[4] K. Hong, J. Xie, L. Zhang, D. Sun, and D. Gong, "Effects of chitosan coating on postharvest life and quality of guava (Psidium guajava L.) fruit during cold storage," Scientia Horticulturae, vol. 144, pp. 172-178, 2012.

[5] C. Fagundes, K. Moraes, M. B. Pérez-Gago, L. Palou, M. Maraschin, and A. R. Monteiro, "Effect of active modified atmosphere and cold storage on the postharvest quality of cherry tomatoes," Postharvest Biology and Technology, vol. 109, pp. 73-81, 2015.

[6] S. A. Valencia-Chamorro, M. B. Pérez-Gago, M. A. Del Río, and L. Palou, "Effect of antifungal hydroxypropyl methylcelluloselipid edible composite coatings on penicillium decay development and postharvest quality of cold-stored "ortanique" 
mandarins," Journal of Food Science, vol. 75, no. 8, pp. S418S426, 2010.

[7] L. Sánchez-González, C. Pastor, M. Vargas, A. Chiralt, C. González-Martínez, and C. Cháfer, "Effect of hydroxypropylmethyl cellulose and chitosan coatings with and without bergamot essential oil on quality and safety of cold stored grapes," Postharvest Biology and Technology, vol. 60, pp. 57-63, 2011.

[8] D. K. Das, H. Dutta, and C. L. Mahanta, "Development of a rice starch-based coating with antioxidant and microbe-barrier properties and study of its effect on tomatoes stored at room temperature," LWT - Food Science and Technology, vol. 50, no. 1, pp. 272-278, 2013.

[9] K. T. Roberts, "The physiological and rheological effects of foods supplemented with guar gum," Food Research International, vol. 44, no. 5, pp. 1109-1114, 2011.

[10] P. Moser, M. L. Cornelio, and V. R. Nicoletti Telis, "Influence of the concentration of polyols on the rheological and spectral characteristics of guar gum," LWT - Food Science and Technology, vol. 53, no. 1, pp. 29-36, 2013.

[11] B. Heyman, W. H. De Vos, F. Depypere, P. Van der Meeren, and K. Dewettinck, "Guar and xanthan gum differentially affect shear induced breakdown of native waxy maize starch," Food Hydrocolloids, vol. 35, pp. 546-556, 2014.

[12] E. P. Cipolatti, L. Kupski, M. da Rocha, M. D. S. Oliveira, J. G. Buffon, and E. B. Furlong, "Application of protein-phenolic based coating on tomatoes (Lycopersicum esculentum)," Ciencia e Tecnologia de Alimentos, vol. 32, no. 3, pp. 594-598, 2012.

[13] A. Ali, M. Maqbool, P. G. Alderson, and N. Zahid, "Effect of gum arabic as an edible coating on antioxidant capacity of tomato (Solanum lycopersicum L.) fruit during storage," Postharvest Biology and Technology, vol. 76, pp. 119-124, 2013.

[14] USDA, U.S. Standards for Grades of Fresh Tomatoes, USDA, Agricultural Marketing Services, Washington, DC, USA, 1991.

[15] X. Ruelas-Chacón, J. C. Contreras-Esquivel, J. Montañez et al., "Water vapor permeabiliy, mecanical, optical, and sensorial properties of plasticized guar gum edible films," in Research Methodology in Food Science Integrated Theory and Practice, C. O. Mohan, E. Carvajal-Millan, and C. N. Ravishankar, Eds., Apple Academic Press, CRC Press, Taylor \& Francis Group, 2017.

[16] A. Tefera, T. Seyoum, and K. Woldetsaik, "Effect of disinfection, packaging, and storage environment on the shelf life of mango," Journal of Biosystems and Engineering, vol. 96, pp. 1537-1550, 2007.

[17] N. Maftoonazad, H. S. Ramaswamy, and M. Marcotte, "Shelflife extension of peaches through sodium alginate and methyl cellulose edible coatings," International Journal of Food Science and Technology, vol. 43, no. 6, pp. 951-957, 2008.

[18] F. Maul, S. A. Sargent, C. A. Sims, E. A. Baldwin, M. O. Balaban, and D. J. Huber, "Tomato flavor and aroma quality as affected by storage temperature," Journal of Food Science, vol. 65, no. 7, pp. 1228-1237, 2000.

[19] J. Lu, M. T. Charles, C. Vigneault, B. Goyette, and G. S. V. Raghavan, "Effect of heat treatment uniformity on tomato ripening and chilling injury," Postharvest Biology and Technology, vol. 56, no. 2, pp. 155-162, 2010.

[20] L. Ahmed, A. B. Martin-Diana, D. Rico, and C. Barry-Ryan, "Effect of delactosed whey permeate treatment on physicochemical, sensorial, nutritional and microbial properties of whole tomatoes during postharvest storage," LWT-Food Science and Technology, vol. 51, no. 1, pp. 367-374, 2013.
[21] E. Aguayo, V. H. Escalona, and F. Artés, "Effect of cyclic exposure to ozone gas on physicochemical, sensorial and microbial quality of whole and sliced tomatoes," Postharvest Biology and Technology, vol. 39, no. 2, pp. 169-177, 2006.

[22] S. R. Bhowmik and J. C. Pan, "Shelf life of mature green tomatoes stored in controlled atmosphere and high humidity," Journal of Food Science, vol. 57, no. 4, pp. 948-953, 1992.

[23] A. El-Ghaouth, R. Ponnampalam, F. Castaigne, and J. Arul, "Chitosan coating to extend the storage life of tomatoes," HortScience, vol. 9, pp. 1016-1018, 1992.

[24] A. Ali, M. T. M. Muhammad, K. Sijam, and Y. Siddiqui, "Effect of chitosan coatings on the physicochemical characteristics of Eksotika II papaya (Carica papaya L.) fruit during cold storage," Food Chemistry, vol. 124, no. 2, pp. 620-626, 2011.

[25] Y. Jiang and Y. Li, "Effects of chitosan coating on postharvest life and quality of longan fruit," Food Chemistry, vol. 73, no. 2, pp. 139-143, 2001.

[26] P. Hernández-Muñoz, E. Almenar, V. D. Valle, D. Velez, and R. Gavara, "Effect of chitosan coating combined with postharvest calcium treatment on strawberry (Fragaria ananassa) quality during refrigerated storage," Food Chemistry, vol. 110, no. 2, pp. 428-435, 2008.

[27] J. Bai, R. D. Hagenmaier, and E. A. Baldwin, "Coating selection for 'Delicious' and other apples," Postharvest Biology and Technology, vol. 28, no. 3, pp. 381-390, 2003.

[28] K. A. Athmaselvi, P. Sumitha, and B. Revathy, "Development of Aloe vera based edible coating for tomato," International Agrophysics, vol. 27, no. 4, pp. 369-375, 2013.

[29] F. Santoso and V. A. Rahmat, "Safety and quality assurance of tomato using aloe vera edible coating," Acta Horticulturae, vol. 1011, pp. 133-140, 2013.

[30] F. Andres, L. Camelo, and P. A. Gumz, "Comparison of color indexes for tomato ripening," Horticultura Brasileira, vol. 22, pp. 534-537, 2004.

[31] L. H. Liu, D. Zabaras, L. E. Bennett, P. Aguas, and B. W. Woonton, "Effects of UV-C, red light and sun light on the carotenoid content and physical qualities of tomatoes during post-harvest storage," Food Chemistry, vol. 115, no. 2, pp. 495500, 2009.

[32] M. A. Aguilar-Mendez, E. S. Martin-Martinez, S. A. Tomas, A. Cruz-Orea, M. R. Jaime-Fonseca, and E. S. Martın-Martınez, "Gelatinestarch films: Physicochemical properties and their application in extending the post-harvest shelf life of avocado (Persea americana)," Journal of Food Science and Agriculture, vol. 88, pp. 185-193, 2008.

[33] G. B. Seymour, J. E. Taylor, and G. A. Tucker, Biochemistry of Fruit Ripening, Chapman and Hall, London, UK, 1993.

[34] O. Yaman and L. Bayindirly, "Effects of an edible coating and cold storage on shelf-life and quality of cherries," European of Food Research and Technology, vol. 220, pp. 579-586, 2002.

[35] AOAC, Official Methods of Analysis (2), vol. 918, Association of Official Analytical Chemists, Arlington, Tex, USA, 1984.

[36] A. M. El-Anany, G. F. A. Hassan, and F. M. Rehab Ali, "Effects of edible coatings on the shelf-life and quality of Anna apple (Malus domestica Borkh) during cold storage," Journal of Food Technology, vol. 7, pp. 5-11, 2009.

[37] P. S. Tanada-Palmu and C. R. F. Grosso, "Effect of edible wheat gluten-based films and coatings on refrigerated strawberry (Fragaria ananassa) quality," Postharvest Biology and Technology, vol. 36, no. 2, pp. 199-208, 2005. 
[38] Ö. Taşdelen and L. Bayindirli, "Controlled atmosphere storage and edible coating effects on storage life and quality of tomatoes," Journal of Food Processing and Preservation, vol. 22, no. 4, pp. 303-320, 1998.

[39] R.-Y. Zhuang and Y.-W. Huang, "Influence of hydroxypropyl methylcellulose edible coating on fresh-keeping and storability of tomato," Journal Zhejiang University Science, vol. 4, no. 1, pp. 109-113, 2003.

[40] S. A. Valencia-Chamorro, L. Palou, M. Á. del Río, and M. B. Pérez-Gago, "Performance of hydroxypropyl methylcellulose (HPMC)-lipid edible coatings with antifungal food additives during cold storage of 'Clemenules' mandarins," LWT - Food Science and Technology, vol. 44, no. 10, pp. 2342-2348, 2011.

[41] P. J. Zapata, F. Guillén, D. Martínez-Romero, S. Castillo, D. Valero, and M. Serrano, "Use of alginate or zein as edible coatings to delay postharvest ripening process and to maintain tomato (Solanum lycopersicon Mill) quality," Journal of the Science of Food and Agriculture, vol. 88, no. 7, pp. 1287-1293, 2008.

[42] M. L. L. Navarro-Tarazaga, M. A. Del Río, J. M. Krochta, and M. B. Pérez-Gago, "Fatty acid effect on hydroxypropyl methylcellulose-beeswax edible film properties and postharvest quality of coated 'ortanique' mandarins," Journal of Agricultural and Food Chemistry, vol. 56, no. 22, pp. 10689-10696, 2008.

[43] F. S. Kittur, N. Saroja, Habibunnisa, and R. N. Tharanathan, "Polysaccharide-based composite coating formulations for shelf-life extension of fresh banana and mango," European Food Research and Technology, vol. 213, no. 4-5, pp. 306-311, 2001. 

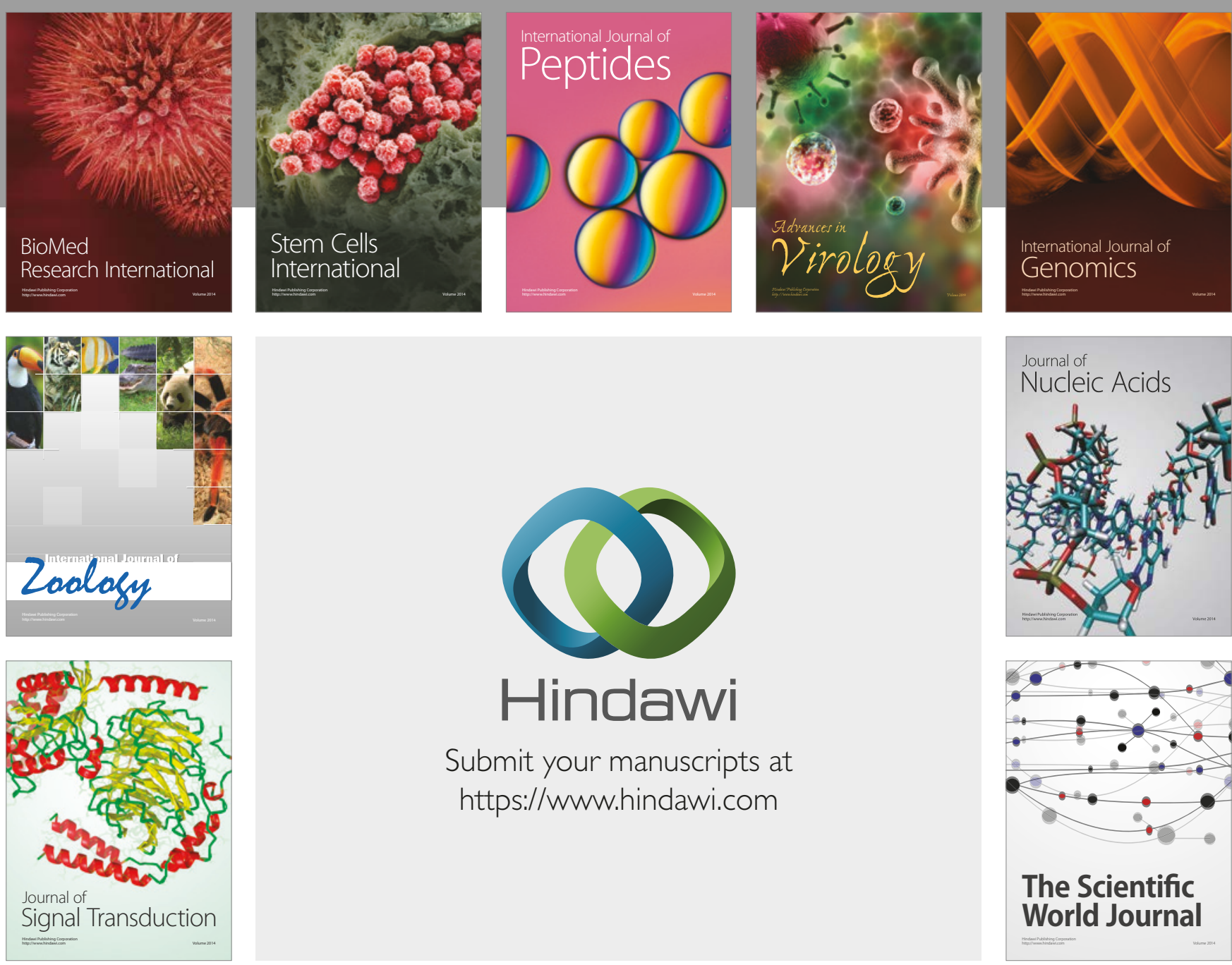

Submit your manuscripts at

https://www.hindawi.com
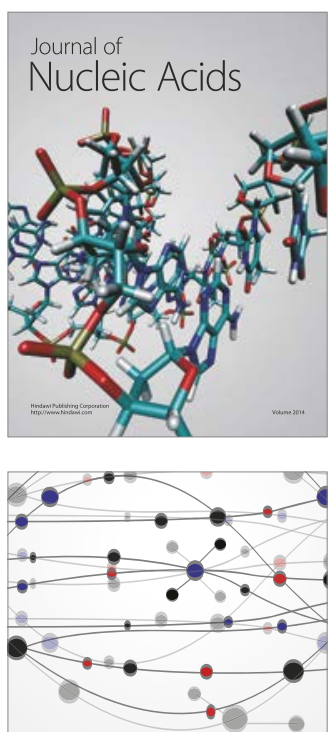

The Scientific World Journal

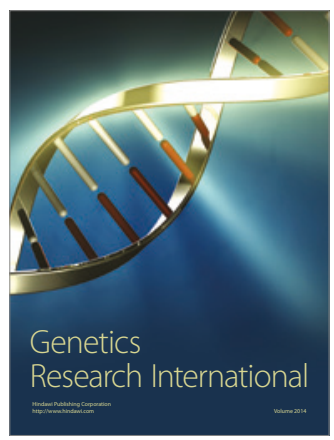

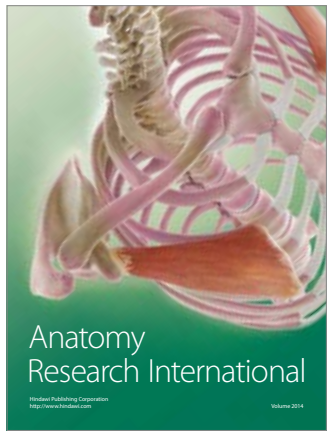

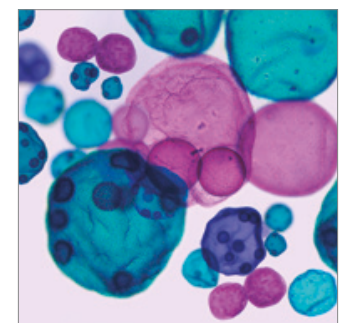

International Journal of Microbiology
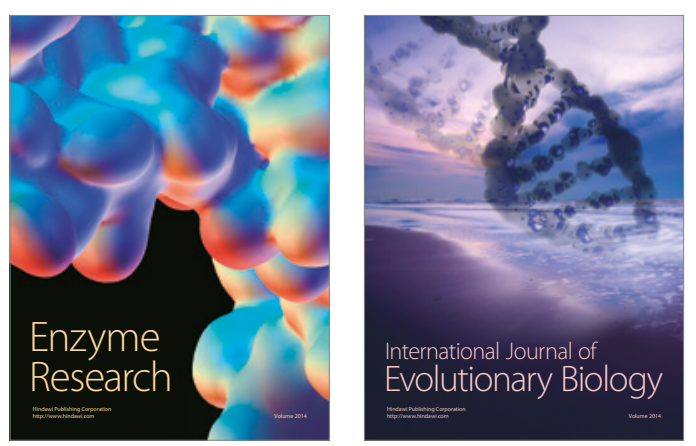
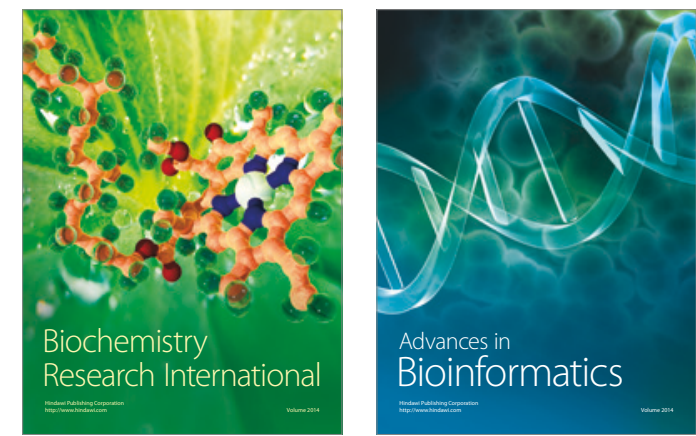

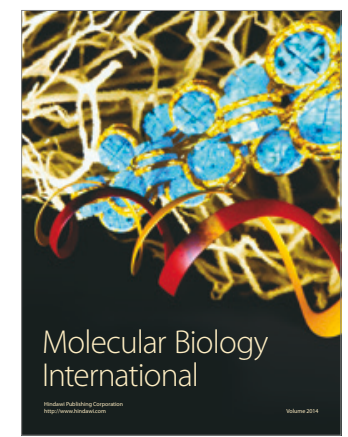

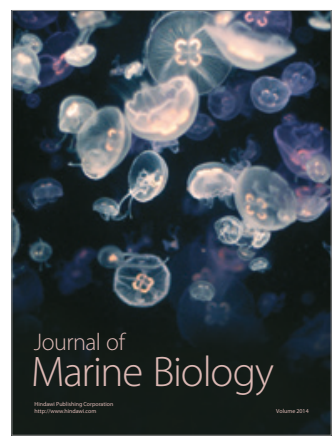

